\title{
Chromosomal heterochromatin differentiation in Salmo trutta with restriction enzymes
}

\author{
LAURA SÁNCHEZ, PAULINO MARTÍNEZ, CARMEN BOUZA \& ANA VIÑAS \\ Departamento de Biología Fundamental, Area de Genética, Universidad de Santiago, 27002 Lugo, Spain
}

\begin{abstract}
Fixed methaphase chromosomes of Salmo trutta were treated with different restriction enzymes. Each enzyme produces a specific banding pattern which demonstrates the value of restriction enzymes for chromosome banding in this species. Digestion with AluI, DdeI, HaeIII, HinfI and MboI indicated the existence of different classes of highly-repetitive DNA. The restriction endonuclease analysis carried out in Salmo trutta trutta and Salmo trutta fario morphae has revealed no differences in respect of heterochromatic distribution and composition.
\end{abstract}

Keywords: heterochromatin differentiation, restriction enzymes, Salmo trutta.

\section{Introduction}

It is now an accepted fact that variability of constitutive heterochromatin appears to be an extended characteristic of vertebrates (Babu \& Verma, 1987). As the result of recent advances in staining techniques it has become possible to recognize heterochromatin regions with great precision in several groups (see for review John, 1988).

Few studies of heterochromatin differentiation on the chromosomes of fishes are available primarily for reasons which relate to the general difficulty in working with fish chromosomes (Gold \& Amemiya, 1986). In Salmonids, these analyses have been performed mostly by C-banding (Zenzes \& Voiculescu, 1975; Thorgaard, 1976; Hartley \& Horne, 1984; Lee \& Wright, 1981), and Q-banding and chromomycin (CMA3) staining (Abe \& Muramoto, 1974; Phillips \& Zajicek, 1982; Phillips \& Hartley, 1988; Mayr et al., 1988). In situ treatment with restriction endonucleases (REs) has proved very useful to reveal heterochromatic regions, because these enzymes are able to digest DNA from fixed chromosomes demonstrating specific regions enriched in target sequences for each enzyme (Miller $e t$ al., 1983; Mezzanotte et al., 1983).

The application of restriction enzymes methods has been extensively used in the analysis of the nature and distribution of heterochromatic regions in mammalian chromosomes (see for review Babu, 1988). Miller et al. (1983) have suggested that the technique of restriction endonuclease (RE) banding could be used particularly on the chromosomes of fish and amphibians, which do not readily band using conventional banding methods. However, few attempts have been made until now to analyse fish chromosomes with RE banding (Lloyd \& Thorgaard, 1988; Cau et al., 1988; Sánchez et al., 1990), although the results seemed to give clear improvements in chromosome classification and heterochromatin differentiation.

In an attempt to characterize the nature and distribution of heterochromatin regions in Salmo trutta (morphae fario and trutta) we have employed RE digestion on fixed chromosomes. Our results show that different subsets of highly-repetitive DNA can be detected, demonstrating a great heterogenity for the heterochromatin in this species. Additionally, we have not found heterochromatic differences between sea and brown trout (trutta and fario, respectively) on the basis of RE banding.

\section{Materials and methods}

Fifteen adult individuals of brown and sea trout (eight and seven, respectively) were collected from different rivers of Galicia (northwest of Spain). Chromosome preparations were obtained from lymphocyte cultures as previously described in Sánchez et al. (1990). For $\mathrm{C}$-banding, slides were incubated in $0.2 \mathrm{~N} \mathrm{HCl}$ for 50 min, dipped into saturated $\mathrm{Ba}(\mathrm{OH})_{2}$ at $37^{\circ} \mathrm{C}$ for $30 \mathrm{~s}$ to $1 \mathrm{~min}$, and incubated in $2 \times \mathrm{SSC}$ at $60^{\circ} \mathrm{C}$ for $15 \mathrm{~min}$. Slides were stained in 10 per cent Giemsa for $10 \mathrm{~min}$. Fluorochrome staining was carried out using the technique of Schweizer (1976). 
Restriction endonucleases (Boehringer and Pharmacia) suspended in the appropriate buffer were applied in different concentrations and times to the airdried cell suspension as follows. AluI 0:3 $\mathrm{U}^{-1}, 4 \mathrm{~h}$; DdeI $0.5 \mathrm{U} \mu \mathrm{l}^{-1}, 8 \mathrm{~h}$; MboI $1.5 \mathrm{U} \mu \mathrm{l}^{-1}, 12 \mathrm{~h}$; HinfI $1.5 \mathrm{U} \mu \mathrm{I}^{-1}, 12 \mathrm{~h}$; and HaeIII $1.5 \mathrm{U}_{\mu \mathrm{l}^{-1}}, 16 \mathrm{~h}$. Slides were incubated in a moist chamber at $37^{\circ} \mathrm{C}$, washed in distilled water and stained with 5 per cent Giemsa for 5-10 min.

Metaphase chromosomes were photographed on an Olympus Vanox microscope using Kodak Imagecapture film. Representative metaphases were karyotyped for each enzyme for all individuals. Quantitative determinations of heterochromatin amounts were made of enlarged positive prints of C-banded karyotypes from sea and brown trout using a digitizer. The total amount of heterochromatin was measured using the total length of heterochromatic regions divided by total length of all chromosomes.

\section{Results}

\section{Chromosome identification}

The REs employed in the present work give a specific and reproducible banding pattern (Table 1). For each enzyme representative metaphases $(2 n=80)$ were karyotyped for different individuals of brown and sea trout. Since no differences were detected, representa- tive karyotypes of either brown or sea trout are presented for each enzyme (Figs 2-6). Taking into account chromosome size, position of centromere and banding pattern induced by the REs used, the identification of several homologue pairs is possible (from pair 1 to pair 17). A complete karyotype is not available because the classification of most acrocentric chromosomes is arbitrary.

\section{Restriction endonuclease banding}

In Fig. 1, some chromosomes of the karyotype of Salmo trutta (the metacentrics and the NOR pair) are presented after treatment with the five restriction enzymes and $\mathrm{C}$-banding and CMA3 staining. The action of each enzyme is described taking as reference the C-banding pattern.

\section{Alul (Figs 1 and 2)}

This enzyme produced positive bands in almost all chromosomes of the complement. In general, these bands are larger than those observed after C-banding. The centromeres of metacentric pairs 2 and 6 appeared digested in all metaphases. Telomeres are clearly defined after AluI digestion while with $\mathrm{C}$-banding they show faint staining. The NOR region, C-banded and CMA3 positive, exhibits a peculiar behaviour after AluI treatment, appearing partially

Table 1 Distribution of conventional C-, CMA3 band and restriction enzyme-induced bands in Salmo trutta chromosomes

\begin{tabular}{|c|c|c|c|c|c|c|c|}
\hline Chromosome no. & C-band & Alu-I & Dde-I & Hae-III & Hinf-I & Mbo-I & $\mathrm{CMA}_{3}$ \\
\hline 1 & + & ++ & ++ & ++ & ++ (gap $)$ & + & + \\
\hline 2 & + & $++\left({ }^{*}\right)$ & $++(*)$ & ++ & $+($ gap $)$ & + & - \\
\hline 3 & + & ++ & ++ & ++ & ++ (gap) & + & - \\
\hline 4 & + & ++ & $++(*)$ & ++ & $+($ gap $)$ & + & - \\
\hline 5 & + & ++ & $++\langle *\rangle$ & ++ & $+($ gap $)$ & + & - \\
\hline 6 & + & $++(*)$ & $++\left(^{*}\right)$ & ++ & ++ gap $)$ & + & - \\
\hline 7 & + & ++ & $++\left({ }^{*}\right)$ & ++ & $++($ gap $)$ & + & - \\
\hline 8 & ++ & ++ & ++ & ++ & ++ & ++ & - \\
\hline 9 & ++ & ++ & ++ & ++ & ++ & ++ & - \\
\hline 10 & + & + & + & ++ & + & + & - \\
\hline 11 & ++ & $++(\mathbf{P})$ & $++(\mathrm{D})$ & $++(\mathrm{D})$ & $++(\mathrm{U})$ & $++(\mathrm{U})$ & ++ \\
\hline 12 & ++ & $++\left(^{*}\right)$ & $++(*)$ & $++(*)$ & $++(*)$ & $++(*)$ & - \\
\hline 13 & ++ & ++ & $++\left({ }^{*}\right)$ & ++ & $++(*)$ & ++ & - \\
\hline 14 & ++ & ++ & + & ++ & ++ & ++ & + \\
\hline 15 & + & + & $+\left({ }^{*}\right)$ & + & + & + & + \\
\hline 16 & + & + & $+(*)$ & + & + & + & + \\
\hline 17 & + & ++ & $+(*)$ & ++ & + & + & + \\
\hline
\end{tabular}

+ , Faint bands; + + , bright bands; - , lack of banding; U, undigested NOR region; d, digested NOR region; p, partially digested NOR region; $\left({ }^{*}\right)$, digestion of centromere; gap, digested regions in centromeric areas. 


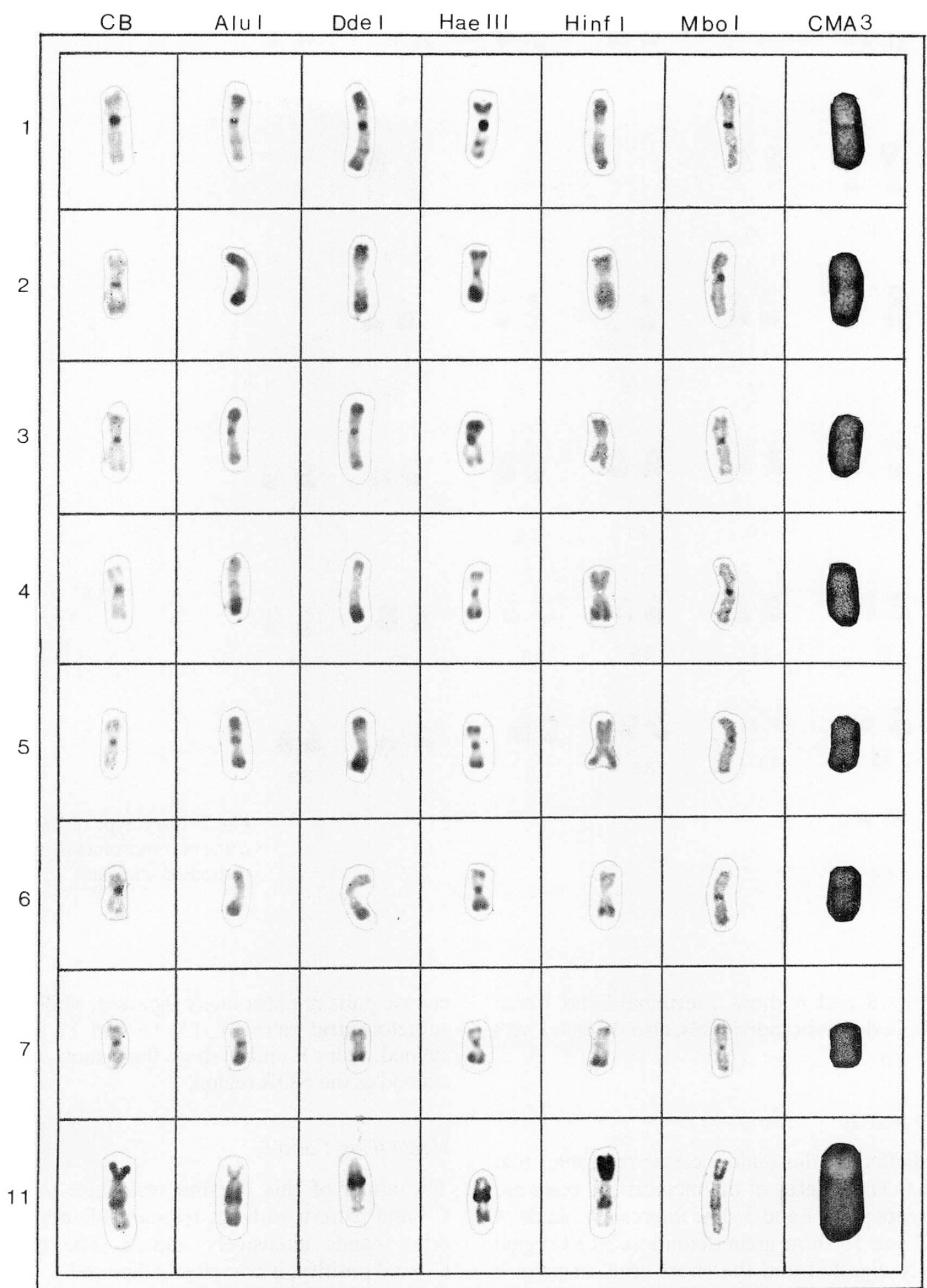

Fig. 1 Banding patterns induced after in situ digestion with restriction endonucleases (AluI, DdeI, HaeIII, Hinfl and MboI) on metacentric chromosomes and the NOR pair. Left and right columns show $C$-banding $(C B)$ and chromomycin staining (CMA3), respectively. 



digested. Pairs 8 and 9 show a terminal band which varies in size in different individuals, also detected with C-banding.

\section{Ddel (Figs 1 and 3)}

The general effect of this endonuclease resembles that of AluI. The centromeres of the metacentric pairs are digested, except pairs 1 and 3 . The intercalary bands of pairs 11,12 and 13 show great definition. NOR region is completely digested and the short arms of pairs 8 and 9 show positive staining.

\section{Hinfl (Figs 1 and 4)}

The endonuclease HinfI shows a peculiar behaviour on trout chromosomes. The centromeres of all meta-
Fig. 2 Karyotype of Salmo trutta m. trutta chromosomes digested with AluI restriction enzyme. centric pairs are absolutely digested, while those of the subtelocentric pairs 14, 15, 16 and 17 are positively stained. Pairs 8 and 9 show their short arms as wellstained as the NOR region.

\section{Haelll (Figs 1 and 5)}

The effect of this enzyme resembles in general the $\mathrm{C}$-band pattern with the telomeres better defined and other bands intensively stained. The NOR region, $\mathrm{C}$-band positive, is completely digested.

\section{Mbol (Figs 1 and 6)}

The restriction enzyme MboI gives the characteristic C-band pattern. All C-positive areas appeared wellstained after digestion with this enzyme. The euchro- 




Fig. 3 Karyotype of Salmo trutta $\mathrm{m}$. trutta chromosomes digested with DdeI restriction enzyme. matin is not digested to the same extent as with the other four enzymes used in this work. The telomeres are faintly stained.

\section{Heterochromatin amount}

Heterochromatin content, measured by the percentage of the total chromosome length of C-banded material, gives values near 24 per cent in Sea and Brown Trout.

\section{Discussion}

The analysis of fixed metaphase chromosomes with restriction enzymes allow us to reveal different subsets of C-bands in Salmo trutta. These results provide some evidence for the existence of various specific classes of highly repetitive DNA in the constitutive hetero- chromatin of this species. Depending on their response to the action of restriction enzymes (also $\mathrm{C}$-banding and CMA3 staining) the heterochromatin could arbitrarily be divided into at least 11 types (Table 2). These data suggest that the heterochromatic substructures of different chromosomes presumably belong to the same heterochromatic type while others are unique (for example centromeres of pairs 12 and 13). Different types of heterochromatin were detected in human (Babu \& Verma, 1986), and orthoptera chromosomes (Sentís et al., 1989; Gosálvez et al., 1987) with this treatment indicating the capacity of restriction enzymes for revealing heterochromatin heterogeneity. So, enzyme banding patterns would directly reflect the molecular nature of heterochromatic regions.

Although data of in situ hybridization techniques are not available in this species, the results obtained after 


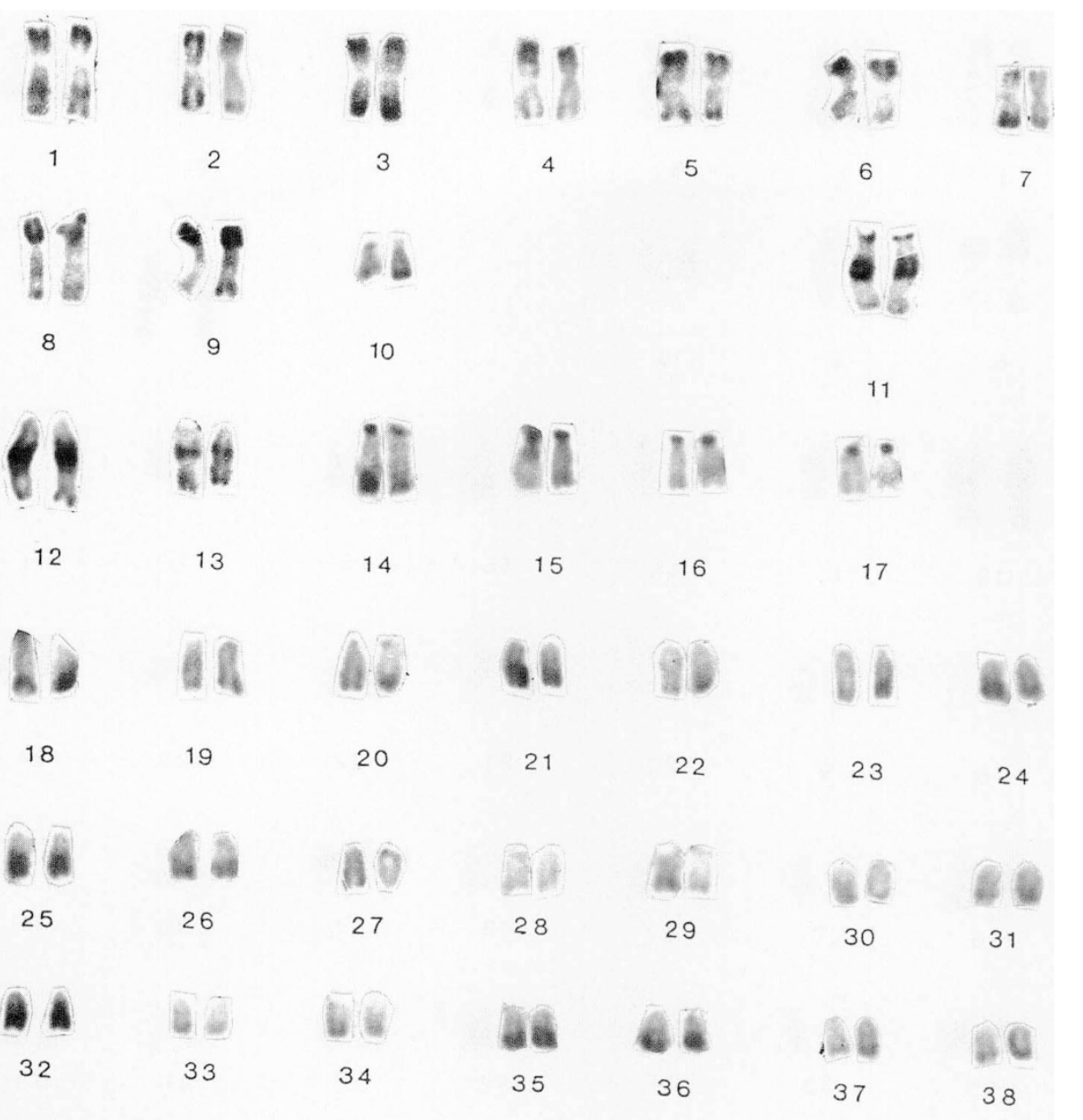

Fig. 4 Karyotype of Salmo trutta m. fario chromosomes digested with HinfI restriction enzyme.

Table 2 Different types of chromatin in Salmo trutta

\begin{tabular}{|c|c|c|c|c|c|c|c|c|}
\hline Types & C-band & Alu-I & Dde-I & Hae-III & Hinf-I & Mbo-I & $\mathrm{CMA}_{3}$ & Chromosome location \\
\hline 1 & + & + & + & + & - & + & - & Centromere M1, M3 \\
\hline 2 & - & - & - & - & - & - & + & Paracentromeric M1 \\
\hline 3 & - & + & + & + & + & + & - & Interstitial band on long arm of M1 \\
\hline 4 & + & - & - & + & - & + & - & Centromere M2, M6 \\
\hline 5 & + & + & - & + & - & + & - & Centromere M4, M5, M7 \\
\hline 6 & + & + & + & + & + & + & - & $\begin{array}{l}\text { Centromere SM8, SM9, SM10; short arm } \\
\text { of SM8, SM9; interstitial band on SM11, } \\
\text { ST12, ST13 }\end{array}$ \\
\hline 7 & + & + & - & - & + & + & + & Short $\operatorname{arm}(\mathrm{NOR})$ and centromere SM11 \\
\hline 8 & + & + & + & + & + & + & + & Short arm and centromere ST14 \\
\hline 9 & + & + & - & + & + & + & + & Centromere ST15, ST16, ST17 \\
\hline 10 & + & - & - & - & - & - & - & Centromere ST12 \\
\hline 11 & + & + & - & + & - & + & - & Centromere ST13 \\
\hline
\end{tabular}

+ , Presence of differential staining (band); negative band; M, metacentric chromosomes; SM, submetacentric chromosomes; $\mathrm{ST}$, subtelocentric chromosomes. 


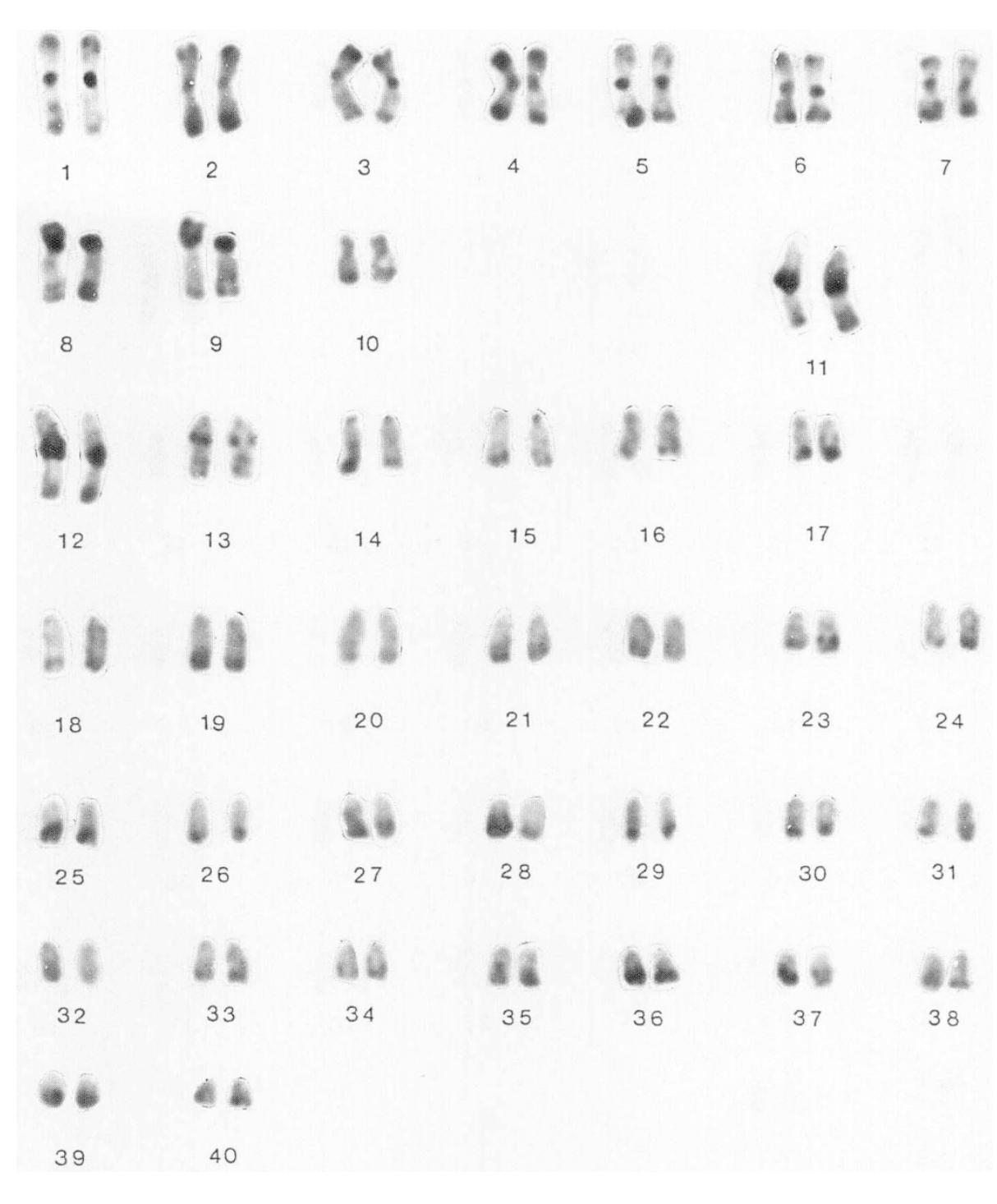

Fig. 5 Karyotype of Salmo trutta m. fario chromosomes digested with HaellI restriction enzyme. treatment with restriction enzymes suggest that heterochromatin displays great molecular heterogeneity. After RE banding some heterochromatic regions appeared differentially digested with the REs used, while others remained undigested, such as the telomeres. It has been suggested that DNA sequences in the heterochromatin are distributed following the principles of equilocality and concerted evolution, based essentially on the distributions of C-bands and fluorescent bands (John et al., 1985). In this sense, the different pattern of digestion found in Salmo trutta after RE treatment (and C-band and CMA3 staining) may suggest that concerted evolution of heterochromatic DNA might have occurred in this species. The telomeres of Salmo trutta probably have homogeneous repeated DNA resistant to the action of several restriction enzymes, thus indicating that these heterochromatic regions would be composed of particular, repetitive DNA sequences, as has been suggested by Rubin (1977) for other organisms. In contrast, in Baetica ustulata Sentís et al. (1989) found that centromeric regions show the same specific pattern of restriction enzyme banding, contrasting with the heterogeneity exhibited by the chromatin of the distal regions.

Polymorphisms of heterochromatin could also be detected after RE treatment in Salmo trutta (terminal bands of pairs 8 and 9, Figs 2-6). The increased amount in one of the two homologues is usually explained by unequal crossover during meiosis. Schmid \& Almeida (1988) have suggested that, if this is true, the enlarged C-bands should respond in a uniform way along their total length after treatment with REs. The terminal C-band of pairs 8 and 9 in Salmo trutta, which varies in size in different individuals (Martínez et al., 1991), show the same behaviour after digestion with all 

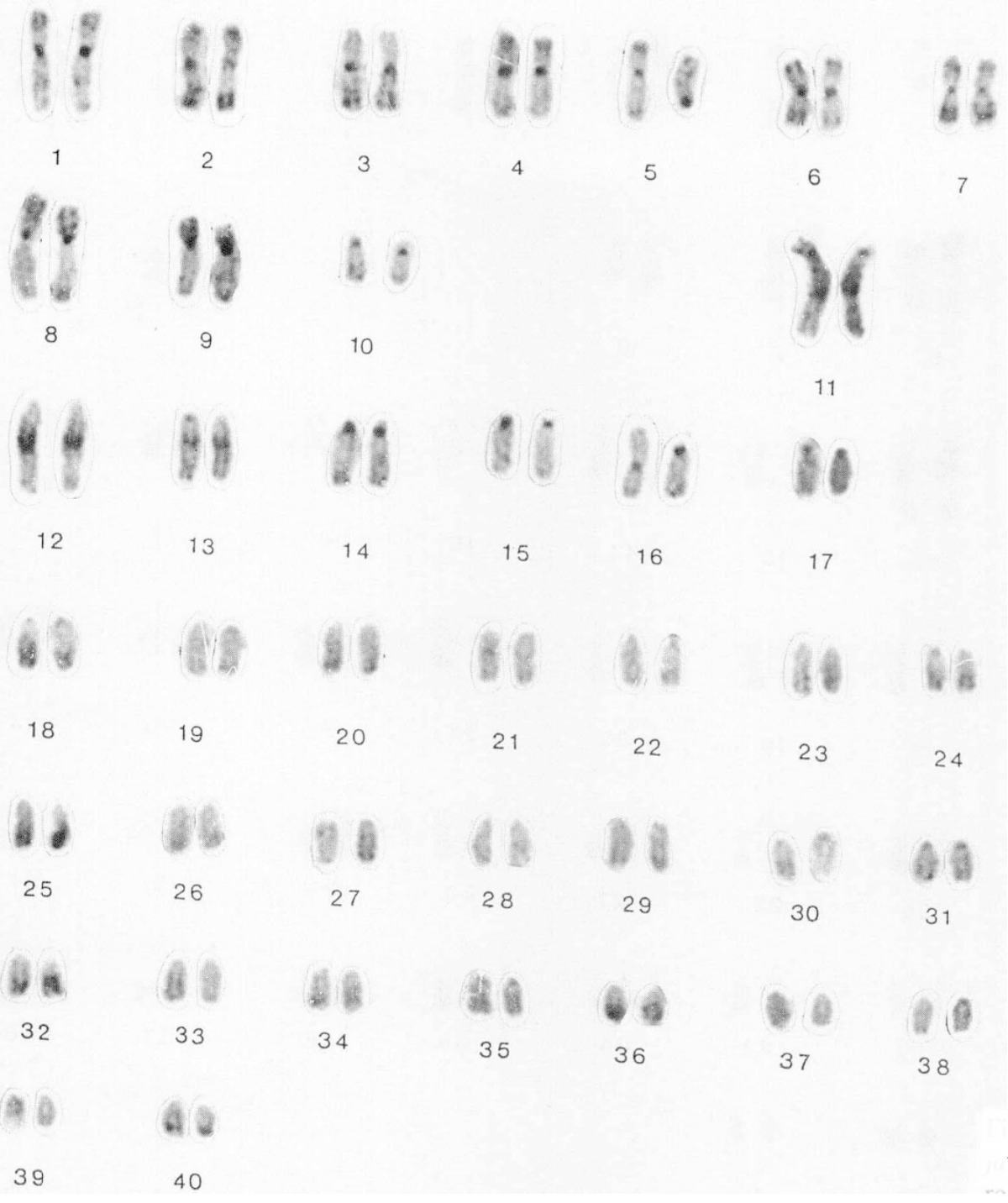

Fig. 6 Karyotype of Salmo trutta m. fario chromosomes digested with MboI restriction enzyme.

the endonucleases tested in this work. So, amplification of similar repetitive DNA in these regions could account for unequal crossover. The use of REs could also be useful for detecting cryptic bands not visible by banding techniques such as C-bands of fluorochromes (Gosálvez et al., 1989). As has been shown here a cryptic band in chromosome pair 1 could be demonstrated after treatment with Alul, Ddel, HaellI, HinfI and $\mathrm{Mbol}$ (Figs 1-6).

The analysis of composition and location of heterochromatic regions in the chromosomes has been extensively used for cytotaxonomic studies. The C-banding and fluorochromes are particularly useful for this purpose (John \& King, 1983; Herrero et al., 1989). In this sense we have applied the technique of $\mathrm{RE}$ banding in a further attempt to detect chromosome differences in two morphae of Salmo trutta (fario and

trutta). The results presented here after in situ digestion with REs are in accordance with our previous data after C, NOR and CMA3 banding in sea and brown trout (Martínez et al., 1991). At the chromosomal level it seems clear that there are no differences between these two morphae. This report demonstrates the value of REs for chromosome banding, characterization of the nature and distribution of heterochromatin and polymorphism analysis in a Salmonid fish, Salmo trutta.

\section{Acknowledgements}

This study was supported by Universidad de Santiago 60902-25038 and Consellería de Agricultura (Xunta de Galicia). The authors want to thank Dr R. Lozano for his excellent technical contributions. 


\section{References}

ABE, S. AND MURAmoto, J. I. 1974. Differential staining of chromosomes of two salmonid species, Salvelinus leucomaenis (Pallas) and Salvelinus malma (Walbaum). Proc. Jap. Acad., 50, 507-511.

BABU, A. 1988. Heterogeneity of heterochromatin of human chromosomes as demonstrated by restriction endonuclease treatment. In: Verma, R. S. (ed.) Heterochromatin: Molecular and Structural Aspects, Cambridge University Press, New York, pp. 250-275.

BABU, A. AND VERMA, R. s. 1986. Characterization of human chromosomal constitutive heterochromatin. Can. J. Genet. Cytol., 28, 631-644.

BABU, A. AND VERMA, R. S. 1987. Chromosome structure: euchromatin and heterochromatin. Int. Rev. Cytol., 108, $1-60$.

CAU, A., SALVADORI, S., DEIANA, A. M., BELLA, J. L. AND MEZZANOTTE, R. 1988. The characterization of Muraena helena L. mitotic chromosomes: karyotype, C-banding, nucleola organizers regions and in situ digestion with restriction endonucleases. Cytogenet. Cell Genet., 47, 223-226.

GOLD, J. R. AND AMEMrYA, C. T. 1986. Cytogenetic studies in North American minnows (Cyprinidae). XII. Patterns of chromosomal nucleolus organizer regions variation among 14 species. Can. J. Zool., 64, 1869-1877.

GOSALVEZ, J., BELLA, J. L., LOPEZ-FERNANDEZ, C. AND MEZZANOTTE, R. 1987. Correlation between constitutive heterochromatin and restriction enzyme resistant chromatin in Arcyptera tornosi (Orthoptera). Heredity, 59, 173-180.

GOSALVEZ, J., LOPEZ-FERNADEZ, C. AND GOYANES, v. 1989. Detection of cryptic bands by AluI in eukaryotic chromosomes. Genome, 32, 672-675.

HARTLEY, S. E. AND HORNE, M. T. 1984. Chromosome relationships in the genus Salmo. Chromosoma, 90, 229-237.

HERRERO, P., BELLA, J. L. AND ARANO, B. 1989. Characterization of heterochromatic regions in two Triturus alpestris subspecies (Urodela: Salamandridae). Heredity, 63, 119-123.

JoHN, B. 1988. The biology of heterochromatin. In: Heterochromatin: Molecular and Structural Aspects, Verma, R. S. (ed.) Cambridge University Press, New York, pp. 1-147.

JoHN, B. AND KING, M. 1983. Population cytogenetics of Atractomorpha similis. I. C-band variation. Chromosoma, 88, 57-68.

JOHN, B., KING, M., SCHWEIZER, D. AND MENDELAK, M. 1985. Equilocality of heterochromatin distribution and heterochromatin heterogeneity in acridid grasshoppers. Chromosoma, 91, 185-200.

LEE, G. M. AND WRIGHT, J. E. JR. 1981. Mitotic and meiotic analysis of book trout, Salvelinus fontinalis. J. Hered., 71, 321-327.

LLOYD, M. A. AND THORGAARD, G. H. 1988. Restriction endonuclease banding of rainbow trout chromosomes. Chromosoma, 96, 171-177.

MARTINEZ, P., VIÑAS, A., BOUZA, C., ALVEREDO, J., AMARO, R. AND SÁNCHEZ, L. 1991. Cytogenetical characterization of hatchery stocks and natural populations of Sea and Brown Trout from Northwestern Spain. Heredity (in press).

MAYR, B., KALAT, M. AND RAB., P. 1988. Heterochromatins and band karyotypes in three species of salmonids. Theor. Appl. Genet., 76, 45-53.

MEZZANOTTE, R., BIANCHI, U., VANNI, R. AND FERRUCCI, L. 1983. Chromatin organization and restriction endonuclease activity on human metaphase chromosomes. Cytogenet. Cell Genet., 36, 562-566.

MILlER, D. A., CHOI, I. C. AND MILlER, O. J. 1983. Chromosome localization of highly repetitive human DNAs and amplified ribosomal DNA with restriction enzymes. Science, 219, 395-397.

PHILliPS, R. B. AND HARTLEY, S. E. 1988. Fluorescent banding patterns of the chromosomes of the genus Salmo. Genome, 30, 193-197.

PHILLIPS, R. B. AND ZAJICEK, K. D. 1982. Q-band chromosomal polymorphismus in lake trout (Salvelinus namaycush). Genetics, 101, 227-234.

RUBIN, G. M. 1977. Isolation of a telomeric DNA sequence from Drosophila melanogaster. Cold Spring. Harb. Symp. quant. Biol., 42, 1041-1046.

SÁNCHEZ, L., MARTÍNEZ, P., VIÑAS, A. AND BOUZA, C. 1990. Analysis of the structure and variability of nucleolar organizer regions of Salmo trutta by $\mathrm{C}, \mathrm{AG}$, and restriction endonuclease banding. Cytogenet. Cell Genet. (in press).

SENTIS, C., SANTOS, J. AND FERNANDEZ-P1QUERAS, J. 1989. Breaking up the chromosomes of Baetica ustulata by in situ treatments with restriction endonucleases. Genome, 32, 208-215.

SCHMID, M. AND ALMEIDA, C. G. 1988. Chromosome banding in Amphibia. XII. Restriction endonuclease banding. Chromosoma, 96, 283-290.

SCHWEIZER, D. 1976. Reverse fluorescent chromosome banding with chromomycin and DAPI. Chromosoma, 58, 307-324

THORGAARD, G. H. 1976. Robertsonian polymorphism and constitutive heterochromatin distribution in chromosomes of the Rainbow Trout (Salmo gairdneri). Cytogenet. Cell Genet., 17, 174-184.

ZENZES, M. T. AND VolCulesCU, I. 1975. C-banding patterns in Salmo trutta, a species of tetraploid origin. Genetica, $\mathbf{4 5}$, 531-536. 